\title{
A COVID-19 Human Viral Challenge Model? Learning from Experience.
}

\author{
Robert Lambkin-Williams ${ }^{1,1}$ and John DeVincenzo ${ }^{2}$ \\ ${ }^{1}$ VirologyConsult Ltd \\ ${ }^{2}$ The University of Tennessee Graduate School of Medicine
}

July 8, 2020

\begin{abstract}
Abstract. The Controlled Human Infection Model and specifically the Human Viral Challenge Model are not dissimilar to standard clinical trials while adding another layer of complexity and safety considerations. The models deliberately infect volunteers, with an infectious challenge agent $(\mathrm{CA})$ to determine the effect of the infection and the potential benefits of the experimental interventions. The Human Viral Challenge Model studies can shorten the time to assess the efficacy of a new vaccine or treatment by combining this with the assessment of safety. The newly emerging SARS-COV-2 virus is highly contagious and the cause pandemic disease COVID-19. An urgent race in is on to develop a new vaccine against this virus in a timeframe never attempted before. The use of the Human Viral Challenge Model has been proposed to accelerate the development of the vaccine. In the early 2000's the authors successfully developed a pathogenic Human Viral Challenge Model for another virus for which there was no effective treatment and established it to evaluate potential therapies and vaccines against Respiratory Syncytial Virus. The authors feel that the experience gained in the development of that model can help with the development of a COVID-19 HVCM and describe it here. Word count: 197
\end{abstract}

\section{Hosted file}

Manuscript submitted 07072020.docx available at https://authorea.com/users/323495/articles/ 468030-a-covid-19-human-viral-challenge-model-learning-from-experience 